\title{
Vírgenes, madres y doncellas. Ser mujer durante el Franquismo a través del humor gráfico de La Nueva España
}

\section{Virgins, Mothers and Maids. Being a woman in Francoism through the graphic humor of La Nueva España}

\begin{abstract}
RESUMEN
El humor gráfico es una importante fuente de información que nos conecta, a través de lo instantáneo, a las mentalidades y pensamientos de las ideologías predominantes de cada época. El uso de determinados estereotipos, a través de la cotidianeidad y de lo «inofensivo» del humor, no hace sino perpetuar comportamientos y normalizar circunstancias que afectan a la mujer. A través del humor gráfico publicado en La Nueva España, uno de los periódicos del Movimiento, analizaremos la producción de la nueva imagen de la mujer española a partir de la instauración de la Dictadura a través de tres situaciones prototípicas que construyen el ideal franquista de madre y esposa: la soltería, el noviazgo y el matrimonio.

Palabras clave: humor gráfico, mujer, franquismo, dictadura.
\end{abstract}

\begin{abstract}
The Graphic humor is an important source of information. It connects us to the mentality and thinking of the principal ideology of the time. The graphic humor, by its use of sterotypes, perpetuates lifestyles and normalizes wrong circumstances that affect to women. Through the graphic humor published in La Nueva España, one of the newspapers of the Movimiento, we analyze the production of the new Spanish woman imaginary after the dictatorship instauration through three prototypical situations that build the pro-Franco ideal of women as mother and wife.
\end{abstract}

Keywords: graphic humor, woman, francoism, dictatorship.

\section{SUMARIO}

1. Introducción. 2. Contexto histórico. 3. La soltería. 4. El noviazgo. 5. El matrimonio. 6. Conclusiones. 7. Bibliografía.

\section{Introducción}

El presente artículo aborda la construcción del género a través del humor gráfico de La Nueva España, un periódico regional asturiano líder en ventas, y que, junto al diario Arriba, fue uno de los primeros de la llamada Cadena de Prensa del

1 Universidad de Oviedo, tetelaviana@hotmail.com 
Movimiento en el franquismo². La naturaleza del periódico La Nueva España está marcada por la ideología de la falange, como bien podía leerse en su cabecera: La Nueva España. Diario de la Falange Española y de las JONS. Lo que nació en un primer momento como noticiario de guerra, pronto se convierte en uno de los periódicos más influyentes del norte de España, incluyendo en sus páginas noticias de deportes, sociedad, sucesos, arte y cultura, además de los espacios reservados para el entretenimiento. De entre la gran variedad temática sobre la que versa el humor gráfico del periódico, hemos seleccionado las aquellas representaciones que tienen que ver con la construcción de las mujeres y de los hombres plasmándolos ante diferentes situaciones y circunstancias. Especialmente, nos centraremos en tres ámbitos la soltería, el noviazgo y el matrimonio, en los que veremos cómo la prensa gráfica dialoga con los preceptos de género del franquismo. Estas tres situaciones permiten conectar los principales elementos de la construcción social del género con los fundamentos del franquismo sobre el lugar que ocupan las mujeres en la sociedad y que, como vemos, refuerza la idea de domesticidad y centralidad de la búsqueda de marido para conseguir el mandato franquista de buena madre y esposa.

Para el análisis de las imágenes se parte de las siguientes cuestiones: ¿qué es lo que se representa en las viñetas? ¿qué niveles de significado existen? Y ¿por qué esas imágenes llegan a revelarnos la manera de pensar de un periodo histórico determinado? Se toman como referencia dos teorías: la semiótica visual de Roland Barthes y la iconografía de Erwin Panofsky, desde las cuales se pretende averiguar qué es lo que aparece representado, qué ideas, valores, lugares o cosas se representan, y el contexto en el que la imagen es producida y promovida y cómo y por qué los significados culturales y sus expresiones visuales no pueden desligarse de lo meramente histórico.

La selección de las viñetas que se presentan en este artículo, obedece a la clasificación realizada correspondiente a la iconografía de la mujer, que comienza en la década de los 40 y termina en la década de los 70, ya que, a partir de 1973, el periódico enfoca sus viñetas o chistes hacia el panorama político y no tanto al social o cultural, debido a los cambios que se desarrollan en el devenir histórico de nuestro país. No obstante, cabe destacar que el periodo analizado es muy amplio y la realidad social de las mujeres cambió sustancialmente a través de las diversas etapas del franquismo. Es por eso que, en primer lugar, contextualizaremos históricamente la posición social de las mujeres bajo el franquismo para después detenernos en la construcción que el humor gráfico de La Nueva España realiza sobre la soltería, el noviazgo y el matrimonio.

2 Este artículo se enmarca en un estudio más amplio de tesis doctoral que estudia los setenta y cinco años dela publicación en la que el humor gráfico está presente desde su primer número, publicado el 19 de diciembre de 1936. En los doscientos cincuenta mil archivos de humor gráfico estudiados, clasificados y analizados para la tesis doctoral, se realiza un previo estudio de las diferentes tipologías que componen el humor gráfico, entiéndase: caricatura, viñetas o chistes, tiras cómicas e historietas, realizando una exhaustiva clasificación de las mismas por tipos y por temáticas. Se ha llevado a cabo un estudio de las diferentes teorías del humor existentes desde la antigüedad, además de realizar un análisis iconográfico y semiótico de las distintas tipologías. 


\section{Contexto Histórico}

No es hasta 1939, momento en el que finaliza la Guerra Civil, cuando se estabilizan las ideas de la Sección Femenina. El régimen de Franco hace desaparecer la igualdad jurídica entre hombres y mujeres e inicia un proceso de recuperación de una tradición que supondrá para la mujer el regreso a la reclusión en el interior de su hogar, promulgando la defensa de la familia, y enfatizando sobre la función biológica de la mujer que es, básicamente, alumbrar hijos para la Patria, además de las múltiples campañas de descrédito que llevará en contra del feminismo (Díez, 1995: 23-40).

Una de las principales voces que se alzaron en pro de una vida tradicionalista y de roles secundarios para la mujer fue Pilar Primo de Rivera (Madrid, 19121991) -hermana de José Antonio Primo de Rivera, Jefe Nacional de la Falange Española, quien la nombró jefe de la Sección Femenina en 1934-, y que consideraba «que la mayoría de las mujeres de España estaban "sin formar" o "deformadas interiormente" $"$ :

...y el conocer los más elementales deberes que como mujer tiene que cumplir para con el hombre, para con la Patria y para con Dios. Claro que no son ellas las culpables, sino los caducos sistemas antiguos, que les concedieron el voto en las elecciones y quisieron halagarlas a fuerza de piropos, no sabiendo educarlas. Tenemos luego las clases acomodadas que, por haber recibido una formación en Centros de enseñanza más o menos organizados, saben hablar de arte y conocen idiomas extranjeros; pero en cambio, ignoran totalmente cómo se adereza una comida o cómo se plancha un encaje [...] causa del principio del alejamiento de los hombres, que van a buscar a donde sea. Y hasta las mejores, incluso religiosamente, suelen estar deformadas, porque ellas, que no son capaces de cometer un pecado contra el quinto, el sexto y el séptimo Mandamiento, no reparan, a lo mejor, en criticar a una persona o en faltar al Mandamiento del Ayuno con el más leve motivo... (Rodríguez, 2005: 117-198).

Entre las misiones de Franco como Dictador y único gobernante de la nación se encuentra la de dotar a España de una imagen de cohesión de los pueblos que la conforman, tratando de buscar ese origen de lo español dentro de la historia, remontándose para ello al tiempo de los Reyes Católicos. Una de las misiones será volver a esa España de tradiciones y, para ello, será fundamental controlar las divisiones de género (Flores, 2003: 206-7). Así, a la mujer se la verá como un ser reproductor capaz de traer hijos a la Patria, un ser que cuidará de su familia y de su marido únicamente desde su hacinamiento en el interior del hogar. Como bien señala Scanlon acerca de la situación que vivía la mujer a principios de la década de los cuarenta «el deseo de igualarse con el hombre era "pedante, ridículo y camino seguro del fracaso como mujer"; era tarea de la mujer tratar de comprender a su marido y el hacer más interesante y atractiva la vida del hogar» (Scanlon, 1976: 324). Y para evitar todo tipo de acercamiento al sexo opuesto, la Sección Femenina se encarga, siempre bajo la supervisión de Franco, de diseñar un nuevo estereotipo 
para la creación de la nueva España. «El hogar y la familia se convierten en la institución primordial del régimen» (Quero, 2003: 459).

Toda la ideología empleada dentro de Sección Femenina versa sobre los principios falangistas y del catolicismo, convirtiendo a Isabel la Católica y a Santa Teresa de Jesús en sus más altas figuras y ejemplos a seguir. Desde este grupo femenino se lleva el control exclusivo del Servicio Social de la Mujer, muy semejante al Servicio Militar Obligatorio del hombre; o el Auxilio Social. Además, Franco dona a la Sección Femenina el Castillo de la Mota en Medina del Campo, Valladolid, para que sirva como sede de sus principales actividades:

- Ofréndate abnegadamente a una tarea

- Que tu vida sea abnegación y sacrificio

- No traiciones tu magnífico destino de mujer, entregándote a funciones varoniles

- Busca siempre ser exacto cumplimiento del hombre

- Tú puedes hacerlo, moldea España en el alma del hombre y del niño

- Cuida tu alma y tu cuerpo por Dios y la Falange

- Pon todos tus amores bajo el amor generoso de España

- A la aurora sirva tu corazón a Dios y piensa en un nuevo día para la Patria

- Vive siempre para la Universidad, la Justicia y el Imperio

- No busques para ti la gloria, pero merécela para España y para la falange (Cebreiros, 2009).

La mujer se enfrenta a un periodo de absoluto sometimiento jurídico a la figura masculina, a cualquier hombre de la sociedad; primero se somete a su padre, luego a su marido y también a su jefe. La mujer es considerada un ser inferior incapaz de pensar por sí misma porque «las mujeres nunca descubren nada; les falta, desde luego, el talento creador, reservado por Dios para inteligencias varoniles; nosotras no podemos hacer más que interpretar, mejor o peor, lo que los hombres nos dan hecho» (VVAA, 2013: 56). Además de estas palabras, otras, recogidas en los libros de texto de primero de Bachillerato sobre Formación Político Social llegan a comparar a la mujer con «un algo útil», es decir, un objeto que sirve al hombre, que ayuda al hombre pero que jamás se situará ni siquiera en un lugar ecuánime al hombre a quien sirve. Las mujeres se convierten, gradualmente, en un accesorio que luce, que adorna, que cuida, que sirve, que limpia y ordena. Se convierte en un objeto mecanizado por la rutina excluyendo así todo atisbo de autoestima. Esta conversión hacia lo material, hacia lo aparente, deriva en una nueva preocupación personal hacia la belleza y la salud física. Desde la Sección Femenina se fomenta la práctica de un deporte moderado que mantenga sanas y fuertes a las futuras madres de la patria y, por otro lado, fomenta hábitos de higiene y de estética femenina, tanto a través de su obra social como a través de las páginas de su revista $Y$, y más adelante en Teresa.

Publicaciones que no son exclusivas, sino que, en las páginas de buena parte de los periódicos del Movimiento, se dedican espacios a secciones como Mujer que podemos encontrar en La Nueva España. Estas secciones, dirigidas fundamentalmente al público femenino, recogen todos aquellos aspectos que se consideraban propios de lo que se comprendía como «femenino», aspectos por 
los que sólo y exclusivamente se preocupaban las mujeres como la moda y sus principales tendencias, el hogar y los trucos caseros tanto para la conservación de los alimentos, como para la limpieza de las manchas en cualquier tipo de tejido; las manualidades, el corte y confección, y algún que otro reportaje vinculado con personajes de cierta posición social, equiparable a lo que hoy conocemos como «prensa rosa».

La imagen de la nueva mujer española, que desde la dictadura se promueve, no deja indiferente a ningún medio de comunicación, ni medio de expresión. No sólo es eso, sino que son los medios de comunicación los portadores de la propaganda del régimen dictatorial siendo conscientes de su gran público. A partid de la década de los 40, tras un episodio de humor bélico, se publica en La Nueva España un humor gráfico que recoge en su minúsculo espacio gran información sobre la moda y las preocupaciones de las mujeres de aquella época. Debemos señalar, por un lado, que los humoristas que participan con su obra en el periódico son hombres y realizan una crítica siempre desde la perspectiva masculina, por otro lado, no debemos olvidar algo fundamental y es que el público que consume este medio de comunicación es mayoritariamente masculino.

En la figura 1 nos encontramos con viñetas creadas por el dibujante Alfonso Iglesias que tratan, precisamente, sobre distintas cuestiones, por un lado, la ropa y los accesorios y por otro el maquillaje. El doble sentido o el doble mensaje que nos envía la primera viñeta titulada Otro de sombreritos, deja entrever el pensamiento que se tenía sobre el hecho de la emancipación de la mujer, camuflado, como no, bajo las alas de un sombrero característico de la década en la que se publica el chiste.

\section{Otro de sombreritos.--Por Alfonso}

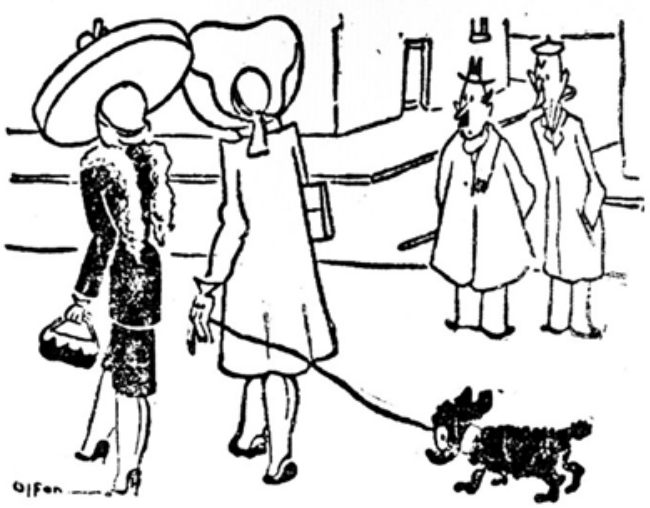

-La mujer médico, la mujer notario, la mujer en la guerra... Le están dando demasiadas alas.

-Si... No hay más que ver los sombreros.

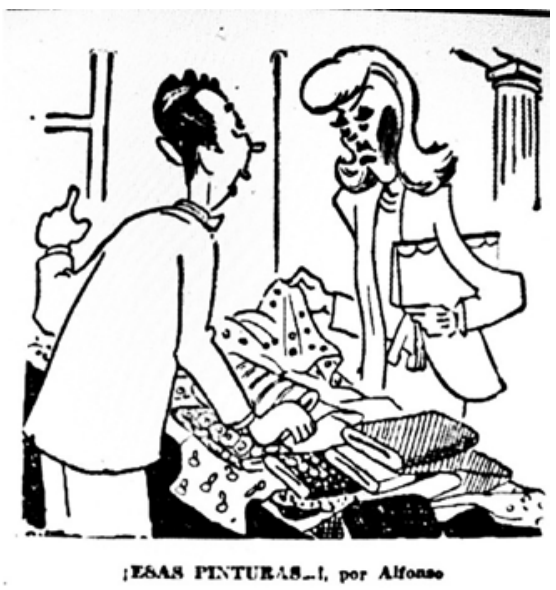

-No me gustan estos tonos. Lo que to quiero es una que me vaya bien a la cara..

-Señorita, usted viene equivocada. Las pastillas de jabón se venden ahi enfrente...

Fig. 1. Otro de sombreritos. ;Esas pinturas...! Alfonso Iglesias. La Nueva España, 11-12-1942, 13-11-1943. 
La imagen nos presenta a dos señoras impecablemente vestidas que pasean a un perro y que se encuentran en el punto de mira de dos señores ubicados en un segundo plano de la representación que hablan entre ellos comentando la escena que se pasea frente a ellos. Uno de ellos dice: «La mujer médico, la mujer notario, la mujer en la guerra... Le están dando demasiadas alas» a lo que el otro personaje responde, algo inocentemente, aprovechando la estética de los sombreros: «Sí... No hay más que ver los sombreros». Un juego de palabras y de conceptos que cuestionan las capacidades profesionales de una mujer por el hecho de ser mujer, y a través del cual cabe recordar aquí la modificación legislativa mediante la que se prohibía el acceso de las mujeres a determinadas profesiones que se consideraron estrictamente masculinas como las que se mencionan en el texto del chiste, por no hablar de la aberración que supuso que las mujeres ocuparan la primera línea de guerra como ocurrió con las milicianas.

El control social que ejerce el franquismo sobre las mujeres a través de la imposición de una mítica de la feminidad que elevaba la discreción y el recato, situaba a las mujeres que no cumplían estos principios bajo sospecha. Lo que se pone, cómo se viste, el uso de maquillaje, etc. será objeto de escrutinio también del humor gráfico que, en este caso, se convierte en objeto de burla. En la segunda viñeta de la figura 1 una señora entra en una tienda para comprar retales de tela para hacerse una blusa. Manifiesta su disgusto ante las tonalidades que el vendedor le ofrece y argumenta que quiere unos tonos que le vayan bien a la cara, a lo que el hombre, un tanto ofendido, le responde: «Señorita, usted viene equivocada. Las pastillas de jabón se venden ahí en frente...». Ante todo prima el juicio del hombre hacia la manera de maquillarse de la mujer frente a la imposibilidad de saber qué tonalidad de piel real tiene la señora y la ofensa de ofrecerle la compra de una pastilla de jabón para lavarse la cara y retirar el maquillaje.

Asiduamente aparecen chistes en los que las mujeres atacan, critican y envidian a otras mujeres, por el hecho de ser más jóvenes, llevar prendas de ropa de más calidad o cualquier otro aspecto que pueda ser objeto de crítica. Se representa así la competitividad entre las mujeres, fundamentada en su superficialidad y apuntalando el mito de las mujeres como enemigas de las mujeres. El humor gráfico redundará en la crítica hacia la apariencia física de las mujeres, que se situará como espacio de acción de la biopolítica franquista.

En la primera viñeta de la figura 2, dos mujeres critican a una tercera conocida con quien se cruzan en una calle. Cuando la distancia que las separa es relativamente amplia, ambas giran el rostro para comentar que a María Elena le han engordado las piernas, a lo que la otra responde que «¡Gastará medias de cristal!...jde aumento...!» «Las medias de nylon, patentadas por Dupont de Memours, llegaban a España a través del contrabando directamente de Estados Unidos y se convertían en un artículo de lujo por su elevado precio» (Abella, 2008: 34).

Llegados a este punto tenemos que las mujeres a finales de los años treinta y durante la década de los cuarenta son presentadas como seres inconscientes y poco inteligentes que han venido al mundo con una finalidad muy específica que es la de traer niños al mundo y cuidar tanto de su hogar como de su marido. Se convierte 

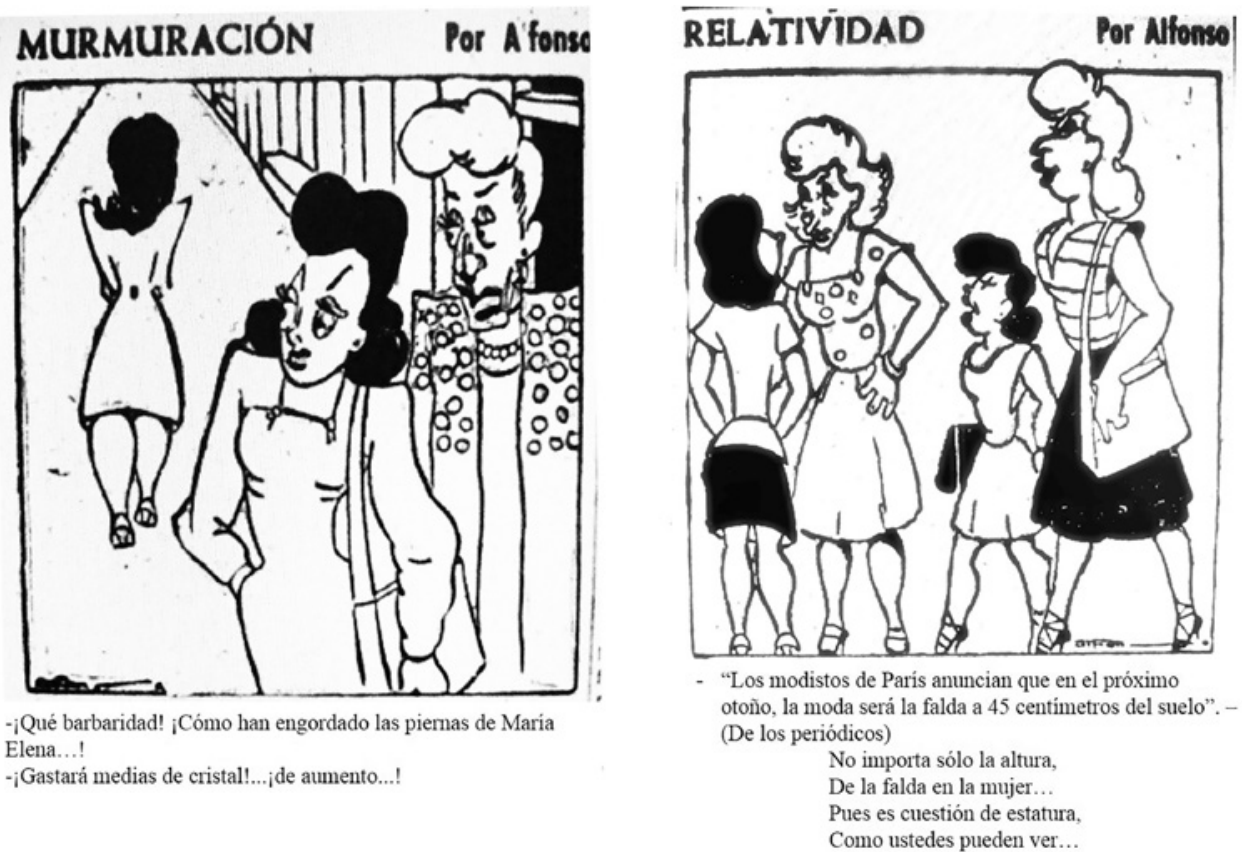

Fig. 2. Murmuración. Relatividad. Alfonso Iglesias.

La Nueva España, 25-04-1948, 14-08-1948.

en un objeto cuya sumisión viene exigida por una sociedad patriarcal en la que no tiene derecho a decidir ni siquiera con quién casarse como veremos más adelante. Pero además las presentan frívolas, superficiales y excesivamente preocupadas por su apariencia física. La apariencia es mucho más importante que el desarrollo de las cualidades personales, por eso se considera que una mujer ha alcanzado el éxito cuando, gracias a su belleza natural y su predisposición a servir y callar, consigue casarse y tener hijos, y, sin embargo, aquella que se dedica a alimentar su alma con estudios al margen de cualquier vida familiar será estigmatizada por la sociedad, y así será reflejado en el humor gráfico. En la segunda viñeta observamos cómo la moda se convierte en un recurso y, donde comienza a notarse cierto cambio en cuanto a la percepción de los hombres hacia las mujeres. Este cambio reside en el hecho de que con la aparición de las medias y con la subida de las faldas de tubo hasta la zona baja de la rodilla, cambio introducido por Christian Dior hacia 1947 más conocido como New Look ${ }^{3}$. La mujer comienza a ser observada como un posible objeto sexual y decorativo para uso y disfrute de los hombres, un hecho este que se establece con más fuerza durante la década de los sesenta.

Tampoco es de extrañar que durante esta década de los 40 los chistes muestren esas obsesiones frívolas femeninas pues tanto en revistas como en periódicos como

3 Para más información sobre el New Look ver https://www.dior.com/couture/es_es/la-maisondior/las-historias-de-dior/la-revolucion-del-new-look 
La Nueva España, comienzan a poblarse con anuncios y suplementos que van cargados de información, que como bien dice Isabel Quero la información está «relacionada con temas de belleza y quehaceres domésticos que se consideran como las principales preocupaciones femeninas. Todos los anuncios tienen como temática dolencias nerviosas dirigidos a un supuesto receptor femenino, potenciando así la imagen de las mismas como eternas enfermas, sujetas a una debilidad física y mental en relación a los hombres» (Quero, 2003: 466).

El final feliz para toda mujer es el matrimonio y esa ansiada protección que, tanto económica como moralmente, sólo podían ofrecer los varones. Como explica Ma Ángeles Larumbe (2004) estos seriales, las novelas rosas o literatura de quiosco, además de los consultorios sentimentales «contribuyeron de modo poderoso, y más hábil que las organizaciones del régimen, a configurar un carácter débil y dependiente en toda una generación de jóvenes españolas».

\section{La soltería}

La soltería era un estigma social. Sofía Rodríguez (2005) afirma que «no es extraño que la dictadura declarara anatemas y antipatriotas a todas las que violaron las fronteras del hogar y la maternidad. La soltería de aquellas que se atrevieron a hacerlo, fue por este motivo objeto de burla y escarnio». Y es que incluso la soltería era considerada como una preocupación nacional objeto incluso de noticias en la prensa como observamos en el primer chiste de la figura 3 en el que podemos leer el siguiente titular: «En España hay más de 800.000 mujeres solteras, según el Instituto Nacional de Estadística». Quienes leen la noticia son dos mujeres en edad madura que consideran su posibilidad de encontrar marido existiendo una competencia semejante. Cabe destacar aquí un aspecto importante y es la imagen que el dibujante ofrece de la mujer soltera, «la solterona». Todas ellas aparecen representadas como mujeres maduras, siendo entendida la madurez como un aspecto negativo, pues va en detrimento de la necesaria jovialidad y belleza, atributos necesarios para encontrar pareja. Son mujeres, por lo tanto, no muy atractivas, con narices prominentes, en algunos casos desaliñadas, o muy bajas o muy altas, o muy gordas o muy flacas. Representación que se aleja de aquellas que sí consiguen el propósito de encontrar un marido y casarse.

La educación de la mujer estaba enfocada sólo y exclusivamente hacia los roles que debía representar en la sociedad: madre y esposa. Esos eran los dos papeles fundamentales que debía desempeñar con esmero, sacrificio y servidumbre. Una clara muestra de lo que aquí se afirma es el establecimiento, por parte del Ministerio de Educación Nacional, del Bachillerato Femenino Obligatorio durante los años 1941 y 1944, donde se menciona que las asignaturas necesarias para conseguir el grado, a parte de las generales como matemáticas, historia o lenguaje, son las de Formación familiar y social, con secciones de corte y confección, trabajos manuales, puericultura postnatal, economía doméstica y convivencia social, o cocina (Primo de Rivera, 1961). 


\section{PESIMISMO}

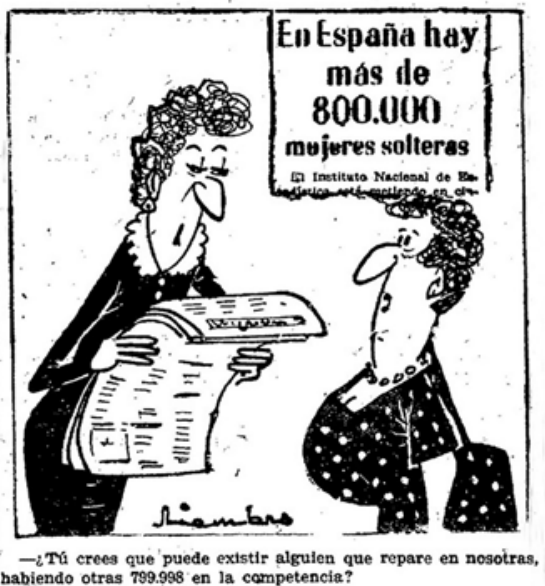

SOLTERAS

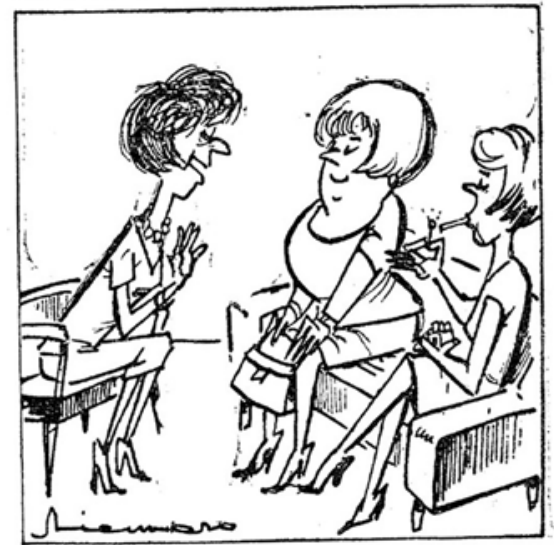

-Pues, anda, que si una se insiruara como las jovenzue las ce ahora..

Fig. 3. Pesimismo. Solteras. Tomás Niembro. La Nueva España, 15-12-1961, 03-12-1965.

Con la exaltación del papel tradicional de la mujer y la glorificación del hogar se tiende a imponer la idea de que el mundo puede progresar perfectamente sin mujeres abogadas, doctoras o científicas, pero de ninguna manera podrá progresar sin las mujeres y su papel natural, el de ser madre o "sacerdotisas en ese templo que alumbren el espíritu familiar con la luz de las celestiales enseñanzas, dirigiendo a sus hijos hacia el bien, la verdad y la belleza» (Scanlon, 1967: 337). La ignorancia de las mujeres se premiaba al igual que ocurría con la belleza, con la discreción y el silencio. Una mujer demostraba ser más femenina cuando reunía estas cualidades. Por el contrario, si una mujer mostraba un tipo de carácter fuerte e inconformista su destino era la soltería y, por lo tanto, la soledad.

$Y$ es que el estereotipo que se transmitía era perfectamente acorde con el modelo femenino que el régimen deseaba, era una mujer más emocional que inteligente, pasiva, dependiente, insegura, afectivamente inestable y que por lo tanto sus expectativas tienen como horizonte exclusivo el matrimonio (Larumbe, 2004: 22). Pero si tras estudiar bachillerato la mujer decidía completar sus estudios en la Universidad, el abanico de carreras universitarias que se ofrecían para las mujeres serán siempre las vinculadas a las cualidades propiamente femeninas, es decir que podrá estudiar todas aquellas carreras universitarias que deriven en educación, organización y cuidado que traducido en profesiones serán maestra, secretaria o enfermera. Aunque también debemos mencionar que muchas de las mujeres que asisten a la Universidad lo hacen con el fin de conocer chicos o futuros maridos pues recordemos que un alarde de conocimientos ahuyentaría a cualquier tipo de pretendiente (Scanlon, 1976: 352). Los hombres están ahí para ser "pescados» por las mujeres y ellos serán la fuente del alimento para el resto de sus vidas. Pero no sólo el ámbito universitario será el escogido por las chicas para conseguir atraer con sus «virtudes» a un marido sino que también sirven para estos menesteres los clubs o los cafés (Fig. 4.). 
TONTITAS

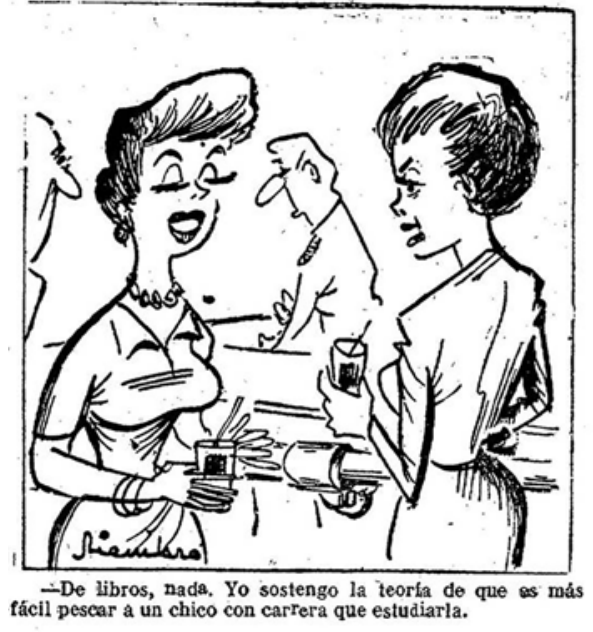

PRETENDIENTES

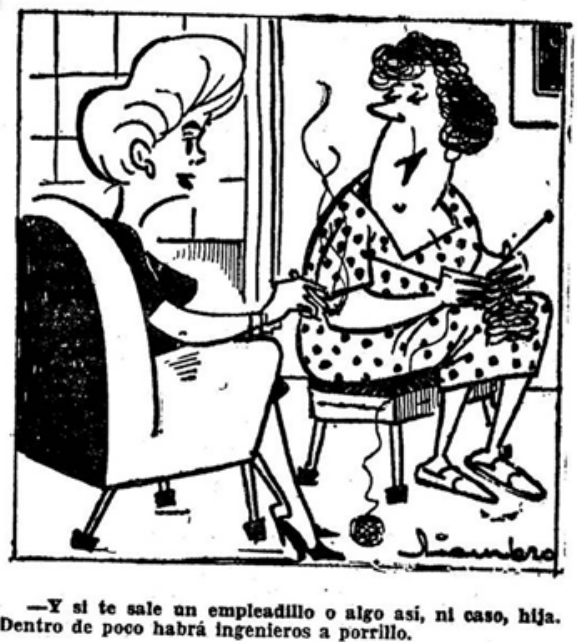

Fig. 4. Tontitas. Pretendientes. Tomás Niembro. La Nueva España, 14-04-1961, 22-01-1964.

Otra de las cualidades valoradas para la sociedad de la dictadura es la castidad y la pureza de las mujeres, sólo y exclusivamente de las mujeres, ya que es norma indispensable llegar virgen al matrimonio. «La reputación femenina, lo que se llamaba la decencia, se cifraba en la capacidad de resistencia de la mujer al acoso masculino, a la pérdida de la virginidad» (Abella, 2008: 34). La decencia queda reflejada también en el segundo chiste de la figura 3, donde un grupo de solteras dice que si hoy en día se insinuaran a los hombres como las jovenzuelas ya habrían encontrado a su marido. Ilustra esta delirante situación de insinuación por un lado para atraer la mirada del hombre y de represión por el otro, para evitar «caer en tentaciones», la primera viñeta de la figura 5 donde se muestra la habitación de una soltera cuya pared está plagada de pósteres de ídolos masculinos. Su ingenuidad casta le lleva a apagar la luz cada vez que se quita la ropa para acostarse con el fin de que esos hombres empapelados no vean su cuerpo desnudo.

Una muestra pública de esa decencia era que toda mujer que decidiera salir a dar una vuelta nunca debería hacerlo sola sino en compañía de una amiga, una hermana o de su padre, o de su novio «formal». En los chistes de la época que tratan cuestiones de soltería las mujeres se representan en parejas o en grupos, pues cuando una mujer se ilustra junto a un hombre, o bien es su pretendiente, $\mathrm{o}$ su marido, o su padre o su jefe o un trabajador independiente. La paridad entre hombres y mujeres no existe, ellas son un instrumento para el hombre, siendo su papel secundario.

Mencionamos antes la pureza y castidad como cualidades que aumentan el valor de la mujer en el mercado del amor, pero debemos hacer cierto inciso en cuanto a educación sexual se refiere. El sexo era un tema tabú y solía explicarse con 
metáforas como el «cuento de la cigüeña» que lo único que conseguían era fomentar la ignorancia, la vergüenza y el rechazo a una relación sexual plena (Pérez, 1993). La conciencia de su sexualidad era inexistente para las mujeres pues no debemos olvidarnos que ella no se ha casado para conseguir su propio placer sexual sino para acceder a las proposiciones de su marido y para servir de instrumento de placer a su cónyuge:

Si tu marido sugiere la unión, entonces accede humildemente, teniendo siempre en cuenta que su satisfacción es más importante que la de una mujer. Cuando alcance el momento culminante, un pequeño gemido por tu parte es suficiente para indicar cualquier goce que hayas podido experimentar. Si tu marido te pidiera prácticas sexuales inusuales, sé obediente y no te quejes. Es probable que tu marido caiga entonces en un sueño profundo, así que acomódate la ropa, refréscate y aplícate crema facial para la noche y tus productos para el cabello. Puedes entonces ajustar el despertador para levantarte un poco antes que él por la mañana. Eso te permitirá tener lista una taza de té para cuando despierte. (Sección Feminina de FET y de las JONS, 1961).
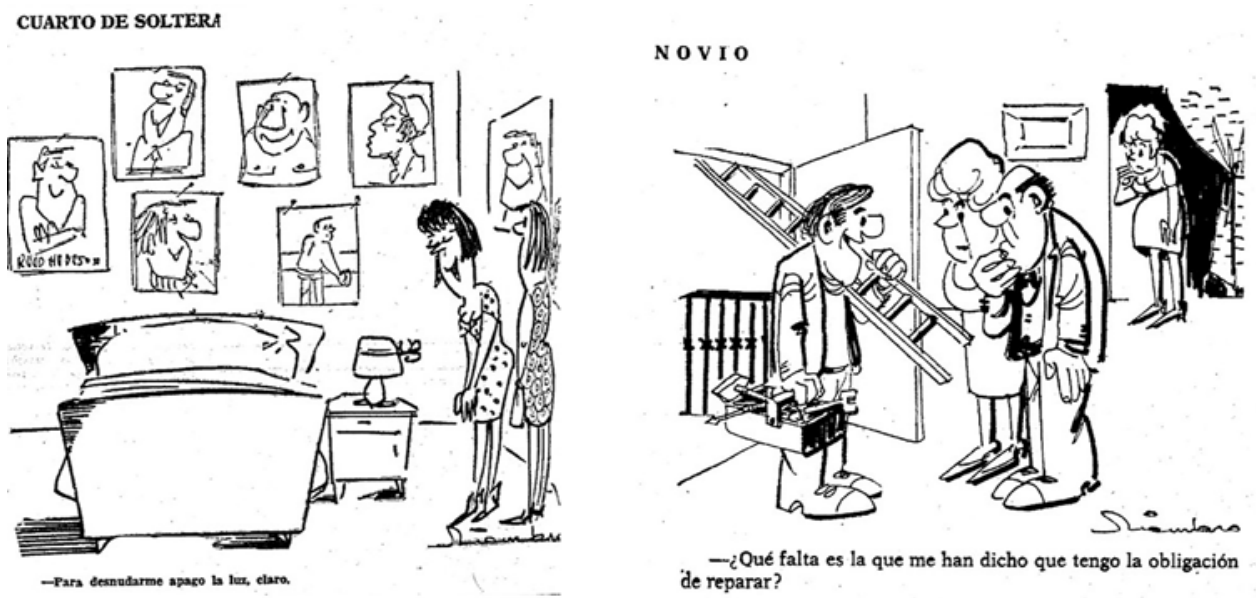

Fig. 5. Cuarto de soltera. Novio. Tomás Niembro. La Nueva España, 22-07-1967, 21-05-1971.

\section{El Noviazgo}

El noviazgo entre dos personas de diferente sexo, pues la homosexualidad no sólo estaba mal vista, sino que era perseguida por la ley, era un periodo de tiempo obligatorio en el que el futuro matrimonio sentaba las bases de su relación. La figura de «novio formal», una denominación que está tardando en irse de nuestro lenguaje más coloquial, llevaba implícita una serie de factores que eran los requeridos por las familias de las mujeres en «edad de merecer». Es decir, el novio debía respetar a su futura esposa y con «respetar» se entendía que no debían mantener relaciones sexuales antes del matrimonio. 
En este punto volvemos a mencionar la castidad como un motivo de elogio para una sociedad en la que la educación y enseñanza de la iglesia católica imponía la segregación de sexos en las escuelas porque consideraba que tanto niños como niñas eran diferentes incluso en la manera de entender las cosas. Así, a los niños se les preparaba para la vida fuera del hogar, como si de futuros soldados patrióticos se tratara, ellos serán los obreros que llevarán el pan a casa y a las niñas se las preparaba para su función biológica: la maternidad.

El sexo se convierte en un instrumento para concebir niños y no de goce o disfrute para ambos miembros de la pareja. La masturbación se consideraba pecado hasta tal punto que a los chicos no se les permitía llevar las manos en los bolsillos del pantalón y se les pedía que pusieran sus piernas en forma de uve invertida. Además, «se afirma que la masturbación o cualquier tipo de relación sexual llevan consigo una serie de consecuencias negativas que actúan directamente sobre el sistema nervioso y óseo, así como también puede producirse una disminución de la capacidad psíquica» (Nielfa, 2003: 50).

Hay que añadir, además, que «el aborto, desde el 24 de enero de 1941, se castiga como delito con penas que pueden llegar hasta los 14 años de prisión mayor» (Larumbe, 2004: 18). Y tampoco existían métodos anticonceptivos al alcance de las mujeres porque la píldora no llegará a nuestro país hasta finales de los 60 , pero su uso no se generalizó por la nube de ignorancia sobre este asunto que el Estado no se preocupaba en disipar.

Y es que «la pureza de una niña era preciosa, y había que proteger su inocencia a toda costa. La educación sexual era imprudente y hasta peligrosa porque las inclinaciones malignas no se dominaban familiarizándose con el pecado» (Scanlon, 1976: 334). El noviazgo es ese periodo de tiempo en el que el futuro matrimonio se prepara concienzudamente para la vida en común. Se convierte en todo un ritual desde el momento del cortejo hasta su culmen en el altar de la iglesia, porque debemos recordar que era un camino hacia adelante en el que no cabía la posibilidad de dar marcha atrás puesto que el divorcio no existía y los matrimonios eran eclesiásticos.

Para la mujer, prácticamente no existe ni siquiera un periodo de libertad e independencia en el que poder desarrollar su autoestima como persona ya que se encuentra sometida en primer lugar a la figura paterna y en segundo lugar a su futuro marido. El peso del cortejo lo llevaba el hombre. Era él quien en las fiestas o en los clubs se acercaba a las señoritas para iniciar una conversación. De ellas dependía luego rechazar al candidato si éste no era de su gusto, pero en ningún momento llevan la iniciativa. Las «buenas intenciones» es otro tipo de frase hecha que se utilizaba mucho para averiguar si el chico en cuestión tenía planes de futuro con esa chica o, por el contrario, sólo la quería para engañarla y seducirla con fines sexuales y no familiares. El pretendiente debía conocer a los padres de su futura mujer para «formalizar» la relación. Existen documentos que reflejan la preocupación por la permanencia temporal del noviazgo, tendiendo a acortar este periodo hasta un máximo de catorce meses, pues «los noviazgos de más de dos años no estaban bien vistos por la sociedad y se tendía a pensar que no terminaban de buena manera» (Nielfa, 2003: 55). 
Una vez en casa de la novia, el novio deberá charlar sobre todo con el padre de familia que es quien manda dentro del hogar y quien debe dar el visto nuevo a su futuro yerno. Hay infinidad de chistes publicados en este periódico que aluden al momento de la presentación del «novio formal». Básicamente, podrían resumirse en los siguientes puntos: por un lado, están los que reflejan a un padre autoritario y preocupado por el bienestar de su hija que exige al novio que trabaje o que gane el dinero suficiente como para poder mantener a una familia numerosa. Tener dinero para poder sentar las bases de un hogar y formar una familia es un recurso muy utilizado. Luego están las viñetas en las que el padre de familia se preocupa de despachar a su propia mujer y enviarla a pasar largas temporadas con el joven matrimonio, suele vender a su mujer como un excelente robot que limpia, guisa y ordena la casa como nadie. Algunos chistes nos recuerdan que no sólo el dinero era un factor importante al margen de la personalidad, sino que la apariencia era otra de las cuestiones a tratar. Sobre todo, a finales de la década de los sesenta cuando la moda cambia y los hombres empiezan a dejarse el pelo largo, los padres no verán con buenos ojos este tipo de manifestaciones externas, por no hablar del estigma de artistas, poetas y músicos quienes eran considerados como «unos vagos» (Fig. 6.).

\section{YERNO.}
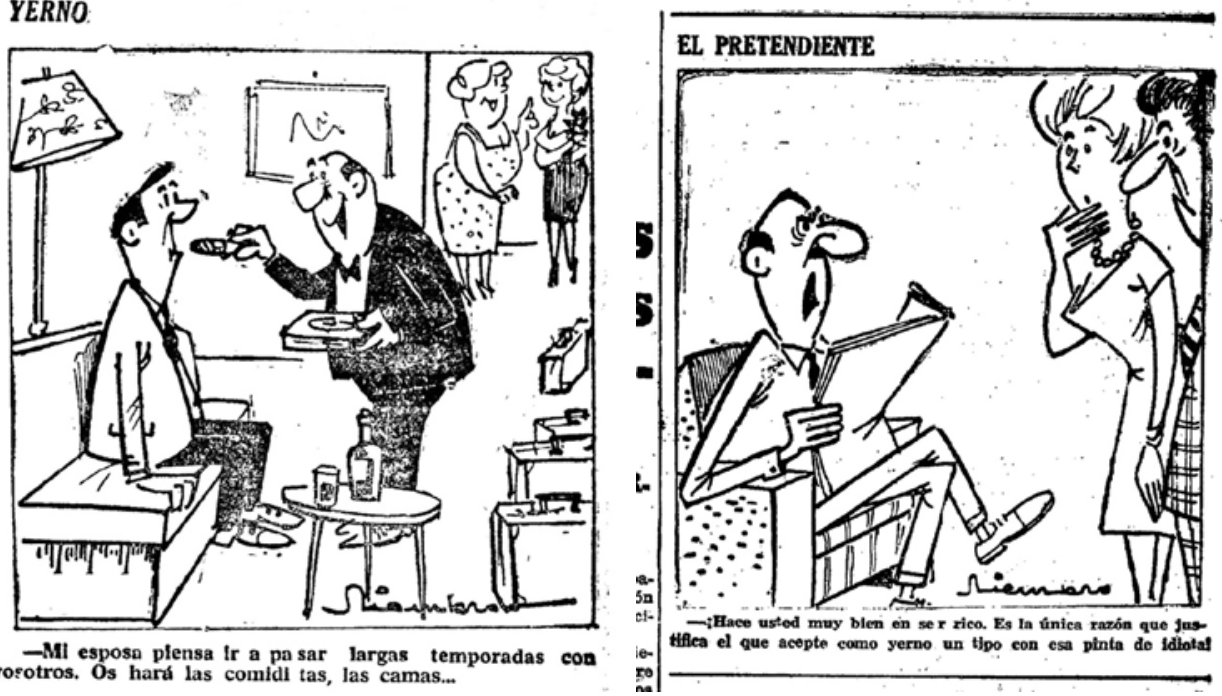

Fig. 6. Yerno. El Pretendiente. Tomás Niembro. La Nueva España, 10-09-1964, 14-06-1962.

Otra de las muestras del control existente sobre la mujer es que los padres del novio no se representan, es decir, que no era necesario que las novias fueran presentadas a los padres del novio como «novia formal». El reparto se hacía entre hombres y el trofeo era la mujer, una mujer sometida y una mujer vista por los hombres desde una óptica bipolar: por un lado, era un objeto de deseo y satisfacción de la voluntad masculina, y por otro es la madre y protectora del hogar pura y 
casta. Lo único que se ha conseguido con este planteamiento es «la segregación entre el placer y la función meramente productiva, provocándose una escisión entre la sexualidad y la maternidad» (Nielfa, 2003: 30-32).

Retomando de nuevo el sexo conyugal y la sexualidad femenina inexistente diremos, para concluir, que la ignorancia por la mayor parte de las mujeres que accedían al matrimonio hacía que esa «noche especial» o «luna de miel» donde, supuestamente, tendría lugar el momento de sellar esa relación, era un momento de frustración y de nerviosismo causados por la casta ingenuidad que la escasa educación sexual se había encargado de promulgar entre las féminas. Observamos en el periódico un gran número de chistes que hacen referencia a esa noche tan ansiada por los amantes en los que las novias son escurridizas, están asustadas, se han emborrachado para perder el conocimiento, o continúan con esa ingenuidad que las hace pensar en el merecido descanso tras un año agotador a causa de los preparativos de la boda.

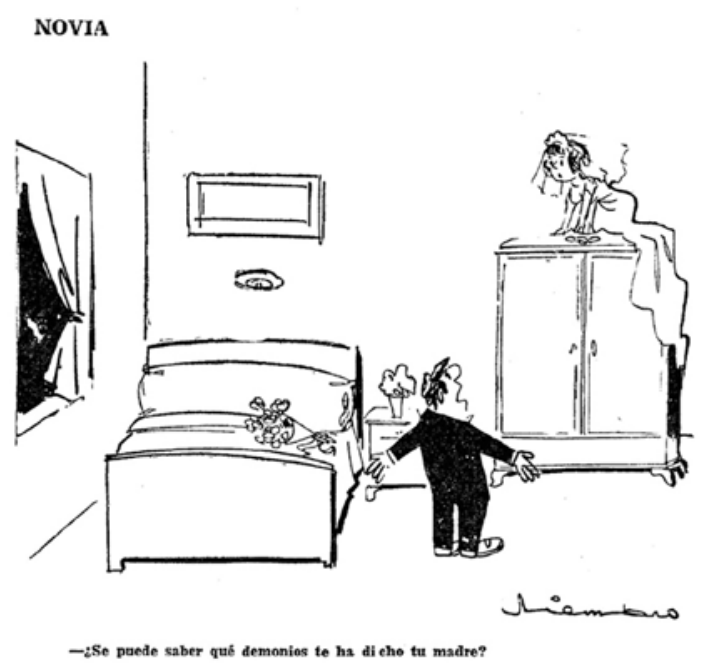

\section{RECIEN CASADA}

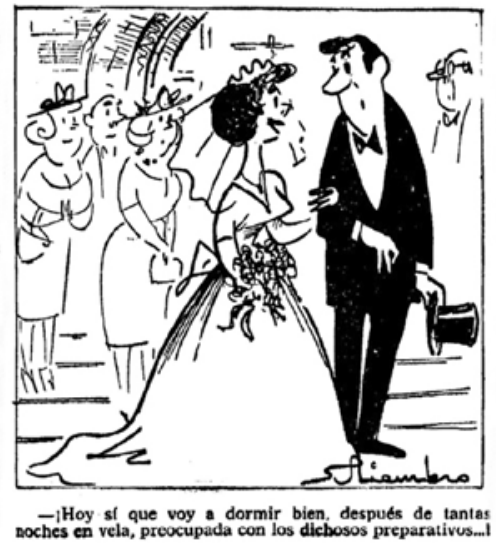

Fig. 7. Novia. El Pretendiente. Tomás Niembro. La Nueva España, 04-04-1967, 22-08-1964.

Esta orientación cultural dentro de una sociedad patriarcal ha quedado en cierta medida anclada en el lenguaje. Álvaro García Meseguer ha demostrado que esto es así en su estudio del diccionario de la Real Academia de la Lengua sobre las palabras que denominan a las relaciones sexuales. Estos términos son unidireccionales y asimétricos, es decir, son definiciones de hombres para hombres, con el valor convenido de la mujer como mero objeto de uso. Uno de los ejemplos es «gozar» que aparece definido como «conocer carnalmente a una mujer» sin darse una definición inversa o mutua. Si a ello añadimos que el verbo «joder» y sus sinónimos, que significan primariamente hacer el acto sexual, se emplean también como equivalentes de fastidiar, causar daño (fenómeno no exclusivo del castellano), veremos confirmado por vía lingüística cómo el varón hasta ahora ha utilizado su 
pene más para violentar que para dar placer, más para hacer la guerra que para hacer el amor. Esta conducta del varón que goza a la mujer (idea de agresión) en vez de amarla (idea de comunicación) se ha impuesto desde la niñez a través del arquetipo de varón, que la cultura ambiental ha transmitido. Y el resultado ha sido «el ejercicio de una sexualidad instintiva, disociada que cosifica a la mujer, en vez de una sexualidad afectiva, integrada, que personifica a la mujer» (Iglesias, 1981: 103-33).

\section{El Matrimonio}

Pilar Primo de Rivera en su discurso inaugural del II Consejo Nacional, celebrado en Segovia en 1938 declararía que «un verdadero deber de las mujeres para con la patria es formar familias con una base exacta de austeridad y de alegría, en donde se fomente todo lo tradicional, en donde se canten villancicos el día de la Navidad, alrededor del Nacimiento...» (Cebreiros, 2009). Iniciamos este punto mencionando las palabras de Pilar Primo de Rivera para observar el contraste que se da entre la pretensión del júbilo de las familias españolas frente a las realidades que cada matrimonio padecía. Hemos podido observar que la alegría dentro del matrimonio no existe en el humor gráfico salvo para reírse de las desgracias o infortunios del cónyuge, e incluso para convertirlo en objeto de mofa colectiva. En este sentido ambos sexos se ven afectados de alguna manera, aunque predomina la imagen de la mujer como objeto de crítica negativa y risa por parte del hombre. Buena parte de las representaciones juegan con el descontento que causa la vida conyugal y se juega con clichés que muestran a una mujer excesivamente preocupada por el orden, controladora, ignorante en algunas ocasiones o, por el contrario, excesivamente charlatana. Ellas muestran su descontento ante la falta de atención de sus maridos y ellos critican la ausencia de belleza física o su pésima forma de cocinar. La relación matrimonial se convierte en un vía crucis insostenible donde el desacuerdo entre las partes es factible y donde el único que puede huir de esa situación es el marido, bien yéndose de juerga o buscándose una querida.

Debemos señalar que el grado de dependencia de la mujer hacia el marido y de incapacidad para comportarse igual que él estaba recogido en el «artículo 28 del Código Penal que permitía al marido matar a la mujer y a su amante, al ser descubiertos yaciendo juntos en el lecho, sin más sanción que seis meses de destierro. Si el daño causado por el esposo vengador era únicamente de lesiones quedaba sin castigo, por más graves o invalidantes que fueran» (Larumbe, 2004: 39). El artículo se modificó sólo a partir de 1963.

Algunos chistes hacen referencia al hombre como un ser incapaz de "poner en su sitio» a su señora, como un pusilánime que se deja mandar y se viste con delantal para fregar los platos o para barrer el hogar mientras su mujer le mira de reojo y vigila que realiza las tareas con orden. Existe también cierta tendencia, dentro del humor gráfico de entonces, a reflejar la psicosis que padecen algunos hombres a ser asesinados por mujeres con el fin de conseguir la pensión de viudedad. 


\section{PONDERACION}

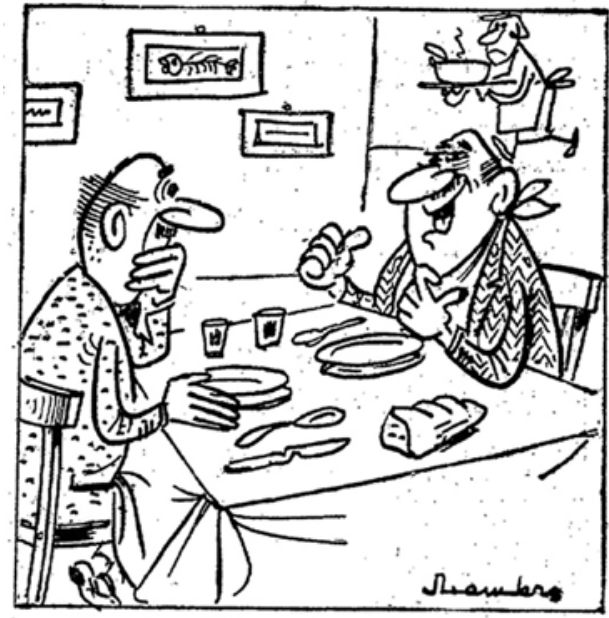

-Ya verás qué biena cocinera es mi señora. iNo hay nadie como ella para poner la fabada de lata!

\section{ENFERMA}

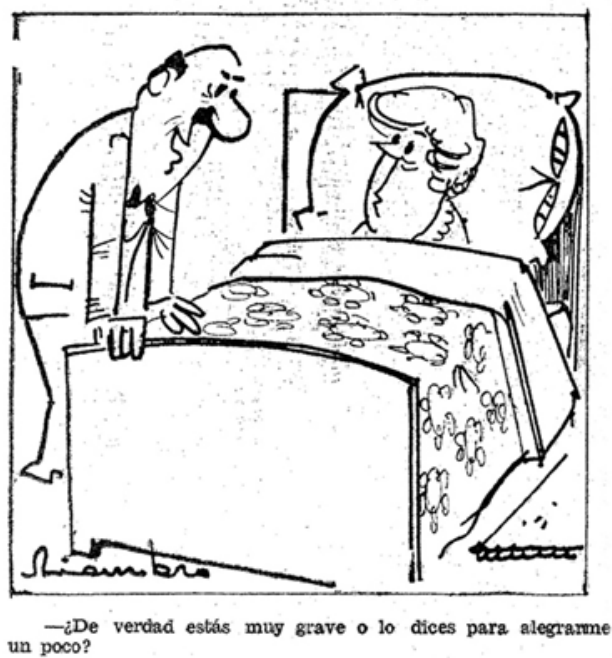

Fig. 8. Ponderación. Enferma. Tomás Niembro. La Nueva España, 04-08-1966, 06-12-1961.

Por otro lado, y teniendo en cuenta cuestiones representativas en las imágenes analizadas, la mujer llevará en numerosas ocasiones el delantal como elemento indicativo de que es ella quien cocina y a quien está destinado ese espacio doméstico. Es ella quien sirve la comida y son ellos quienes siempre estarán sentados a la mesa esperando el plato para realizar la posterior crítica, como ocurre en el primer chiste de la figura 8 donde el marido dice que su mujer es una estupenda cocinera porque no hay nadie que la supere preparando la fabada en lata. Y es que la comida enlatada es un recurso utilizado con frecuencia en aquellos casos que demuestran la incapacidad de la mujer de estar al frente de la cocina.

La mujer que los pretendientes escogían eran aquellas que poseían un físico exuberante, poca inteligencia, calladas o tímidas, ingenuas, así representan a las novias, mientras que las esposas, tras unos años de matrimonio, parecen haberse transformado en una especie de carga que el marido es incapaz de soportar y que busca sus momentos de libertad bien con sus amigos o bien en los clubs de alterne consumiendo prostitución o seduciendo a alguna señorita, como bien se muestra en algunas de estas viñetas.

Esta especie de prisión conyugal a la que el matrimonio se ve sometido no se resolverá hasta la llegada de la ley del divorcio en 1981. Una fecha algo reciente si la comparamos con el resto de Europa. Por ejemplo, en Italia, país donde la Iglesia Católica tenía un peso notable se estableció una ley de divorcio en 1969 que sería rectificada mediante referéndum en 1974. No obstante, en nuestro país comienza a hablarse de la posibilidad de ruptura conyugal en abril de 1971 tras la publicación de un artículo en la revista Triunfo que fue censurado y condenado por el Ministerio 
MERITOS

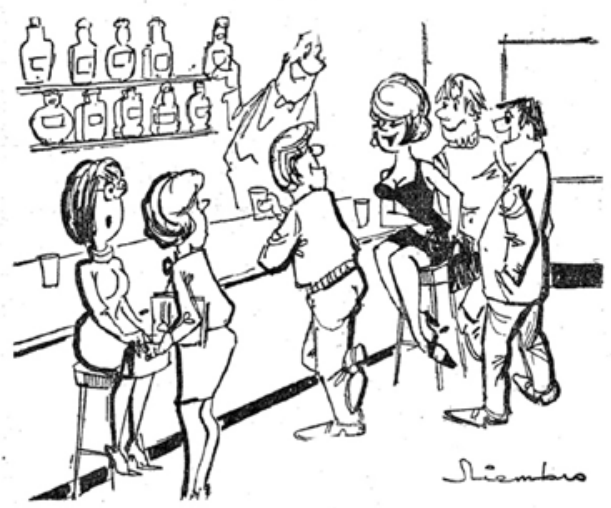

COLADURA

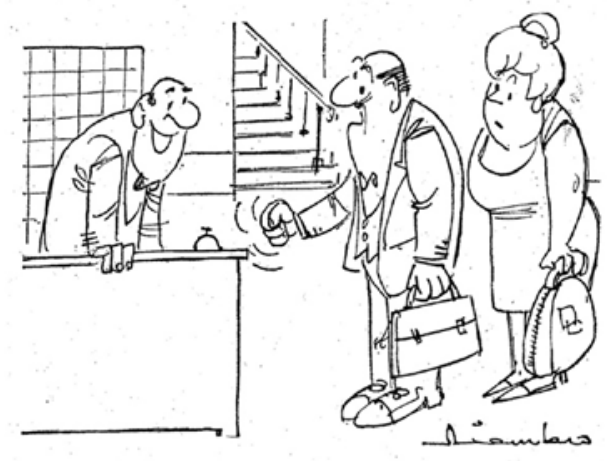

- La misma *suit» que cuando la francesita, seño: Pérez?

Fig. 9. Méritos. Coladura. Tomás Niembro. La Nueva España, 03-03-1967, 22-08-1964.

de Información y Turismo «por ser un alegato a favor del divorcio y en contra del matrimonio y la familia tradicional» (Larumbe, 2004: 34).

\section{Conclusiones}

Mediante el análisis de las imágenes que el humor gráfico nos ofrece, apreciamos una supeditación de la mujer al hombre como padre, marido o jefe, y se ofrece una visión frívola de los intereses de la mujer que se centran en el ámbito doméstico, la belleza o la moda. De hecho, uno de los tópicos que más se reitera en estas viñetas es el de la mujer cuya única aspiración es la de casarse con un hombre rico, con el beneplácito de su padre. Otra de las características que aparece en algunas de las viñetas es la imagen de la mujer como una persona descontenta, confusa y cansada por tener que asumir la sobrecarga de roles como son los de madre y ama de casa, además de apreciar el contrapunto en cuanto a la visión superficial y anodino que tienen los hombres acerca de ambos roles. A través de las viñetas que hemos expuesto en este artículo, queda patente que el futuro de la mujer en los años de la dictadura era conseguir a través de cualquier medio un marido con el que poder formar una familia, el matrimonio se convierte en una especie de jaula para ellos, cuyas libertades parecen truncarse, mientras que para ellas no deja de ser un camino hacia la estabilidad económica. Un estricto precepto de belleza que combina belleza natural pero discreción y «buen gusto» se erige como principal barrera para encontrar pretendientes, así la fealdad o la belleza poco agraciada definirán el camino hacia la soltería y con ello la imposición de la etiqueta «solterona» como algo negativo y de fracaso social.

Todas estas representaciones que, tanto de la mujer como del hombre, aparecen en el humor gráfico de La Nueva España no hacen sino reforzar los estereotipos existentes en buena parte de la sociedad española del Franquismo, pero cabe 
preguntarnos por la función de estos estereotipos. Imágenes que interpelan a la sociedad y que obligan a renegociar las actitudes y la acciones de acuerdo a preceptos que sancionan, ridiculizan y que, al mismo tiempo, son cambiantes y contradictorios. En definitiva, el humor gráfico actúa como regulador de las percepciones sociales sobre cómo deben ser las mujeres -y sus relaciones con los hombres- en contraste a una realidad que era menos estrecha que la que el Franquismo trataba de imponer.

\section{BIBLIOGRAFÍA}

Abella, Rafael (1985): La vida cotidiana en España bajo el régimen de Franco, Barcelona: Argos Vergara.

Cebreiros Iglesias, Ana (2009): «La Sección Femenina. Aproximación a la ideología de una organización femenina en tiempos de Franco», en I Congreso Virtual sobre Historia de las Mujeres.

Díez Fuentes, José Manuel (1995): «República y primer franquismo: la mujer española entre el esplendor y la miseria 1930-1950», en Alternativas: cuadernos de trabajo social, No3, pp. 23-40.

Flores, Raquel (2003): "Género en los carteles del bando nacional en la Guerra Civil Española», en NAsh, Mary, TAverA, Susanna, Las mujeres y las guerras: el papel de las mujeres en las guerras de la Edad Antigua a la Contemporánea, Barcelona: Icaria.

IGLESIAS DE UsSEL, Julio (1981): «La sociología de la sexualidad en España: notas introductorias», en REIS, $\mathrm{N}^{\circ} 21$, pp. 103-133.

LARUMbe, Ma Ángeles (2004): Las que dijeron no Palabra y acción del feminismo en la Transición, Zaragoza: Prensas Universitarias de Zaragoza, Ayto. Zaragoza.

Nielfa CRistóbal, Gloria (2003): Mujeres y hombres en la España franquista: sociedad, economía, política, cultura, Madrid: Editorial Complutense.

PÉrez López, Jesús (1993): El discurso pedagógico relativo a la sexualidad (1940-1962), Madrid: Editorial Universidad Complutense.

Primo de Rivera, Pilar (1961): La enseñanza doméstica como contribución al bienestar de la familia española. Razones de la formación de la Sección Femenina, Madrid: Comercial Española de Ediciones.

Quero Hernández, Isabel y M M $^{\text {a }}$ Dolores JaÉn García (2003): «La imagen de la mujer en la postguerra española a través de la prensa de Almería», en NAsH, Mary, TAVERA, Susanna, Las mujeres y las guerras: el papel de las mujeres en las guerras de la Edad Antigua a la Contemporánea, Barcelona: Icaria.

RodRíguez López, Sofía (2005): «Mujeres perversas. La caricaturización femenina como expresión de poder entre la guerra civil y el franquismo», en Asparkía. Investigació feminista, N¹6, pp. 177-198.

SCANLON, Geraldine (1976): La polémica feminista en la España contemporánea (18681974), Madrid: Siglo Veintiuno de España. 
SECción FEMENINA de Fet y de las Jons (1961): Economía doméstica para bachillerato, magisterio y comercio, Madrid: Almena.

vvaA (2013): Ángela Ruiz Robles y la invención del libro mecánico, Madrid: Ministerio de Economía y Competitividad y Ministerio de Educación, Cultura y Deporte.

Internet:

Las Historias de Dior. La Revolución del New Look. Recuperado de http:/ /www. dior.com/couture/es_es/la-maison-dior/las-historias-de-dior/la-revoluciondel-new-look

Recibido el 29 de julio de 2016 Aceptado el 27 de marzo de 2018 BIBLID [1132-8231 (2018): 75-93] 